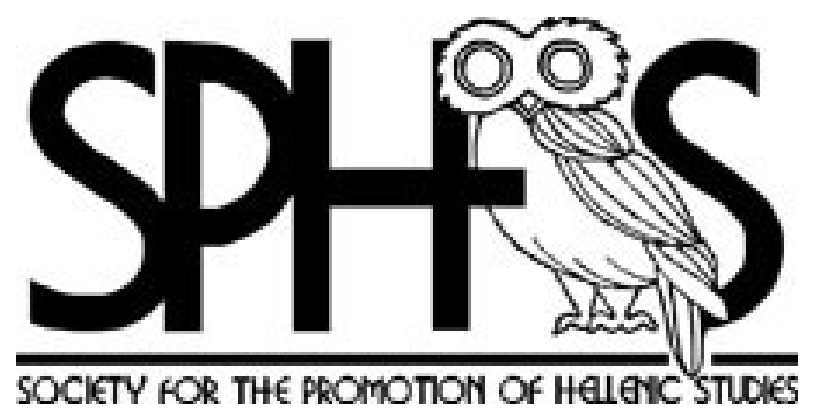

Early States and Hero Cults: A Re-Appraisal

Author(s): James Whitley

Source: The Journal of Hellenic Studies, Vol. 108 (1988), pp. 173-182

Published by: The Society for the Promotion of Hellenic Studies

Stable URL: http://www.jstor.org/stable/632638

Accessed: 21/02/2014 09:33

Your use of the JSTOR archive indicates your acceptance of the Terms \& Conditions of Use, available at

http://www.jstor.org/page/info/about/policies/terms.jsp

JSTOR is a not-for-profit service that helps scholars, researchers, and students discover, use, and build upon a wide range of content in a trusted digital archive. We use information technology and tools to increase productivity and facilitate new forms of scholarship. For more information about JSTOR, please contact support@ jstor.org.

The Society for the Promotion of Hellenic Studies is collaborating with JSTOR to digitize, preserve and extend access to The Journal of Hellenic Studies. 


\section{EARLY STATES AND HERO CULTS: A RE-APPRAISAL}

\section{INTRODUCTION}

AN interest in the Greek idea of the hero, and in the cults established in Greek states to historical or legendary figures endowed with this status, has for long been one of the chief concerns of research into Greek philology and religion. ${ }^{1}$ But it is only through the gradual accumulation of archaeological evidence of Geometric and Archaic date that the origins of 'hero cults' have begun to be seen as an historical problem requiring an historical explanation. The most recent general works on Geometric and Archaic Greece, by J. N. Coldstream, Anthony Snodgrass and François de Polignac, ${ }^{2}$ have long sections devoted to discussing the significance of hero cults, and general 'pan-hellenic' explanations have been offered for their occurrence. Whilst there may be much truth in their suggestions, such 'pan-Hellenic' explanations ignore important local differences in the archaeological and material manifestations of hero cults. These differences, I would argue, relate in part to the different paths that were taken in the formation and development of early states in Greece. I shall use as examples the two regions of Attica and the Argolid, two areas of Greece where differences both in the manifestations of hero cults and in the paths of social evolution can most easily be traced. Before embarking on a detailed comparison of the two areas however, some discussion of the other general explanations that have been put forward is in order.

\section{The Emergence of the Problem}

In 1937, after the publication of Prosymna, Blegen published an article dealing with the postMycenaean finds from the Bronze Age tombs in that cemetery. ${ }^{3}$ It appeared that these finds (which were mainly of Late Geometric or Early Archaic date) were not associated with skeletons, and thus could not be interpreted as grave goods. It was also apparent that the gap in time between the latest Mycenaean finds and the earliest Late Geometric precluded an interpretation of such deposits as evidence for later 'tendance' or veneration of ancestors. J. M. Cook reviewed the evidence for Geometric and Archaic offerings at Mycenae, and noted that this phenomenon coincided with a general revival of interest in the Heroic World. ${ }^{4}$ A systematic overview of all the evidence for Geometric and Archaic deposits in Mycenaean tombs did not appear until Coldstream's important article. ${ }^{5}$ Coldstream, noting, as had Cook, that the practice of placing offerings in Mycenaean tombs was widespread in the late eighth- and early seventhcenturies BC but unknown before, linked this phenomenon to the spread of epic poetry and to a general, contemporary interest in the Heroic World. Indeed he went so far as to imply that the spread of Epic was the direct cause of such a practice. Since his article forms the ground for all subsequent discussion of the issue, it is worth considering its arguments in some detail.

First, Coldstream has defined the phenomenon. What, in archaeological terms, has to be explained is not the appearance of the numerous epigraphically or archaeologically attested cults

${ }^{1}$ For example L. R. Farnell, Greek hero cults and ideas of immortality (Oxford I92I); see also L. Gernet, The anthropology of Ancient Greece (Baltimore 198I) 6-8.

2 J. N. Coldstream, Geometric Greece (London 1977) 346-8; A. M. Snodgrass, Archaic Greece: the age of experiment (London I980) 38-40; F. de Polignac, $\mathrm{La}$ naïsance de la cité grecque (Paris I984) I27-5I.
$3 \mathrm{C}$. W. Blegen, 'Post Mycenaean deposits in chamber tombs', Arch. Eph. c (1937) 377-90.

4 J. M. Cook, 'The cult of Agamemnon at Mycenae' Geras Antoniou Keramopoullou (Athens I953) i I 2-I 8.

$5 \mathrm{~J}$. N. Coldstream, 'Hero cults in the age of Homer', $J H S$ xcvi (1976) 8-I7; see also Coldstream [n. 2] ibid. 
of heroes known from epic poems (such as the cult of Menelaus and Helen at Sparta ${ }^{6}$ or the cult of Agamemnon at Mycenae), ${ }^{7}$ but the practice of placing offerings in Mycenaean tombs. This begins in the late eighth-century $\mathrm{BC}$ (and not before), ${ }^{8}$ and appears to be directed towards figures who, for us at least, remain anonymous. In attributing the cause of this practice to the circulation of epic, Coldstream has emphasised that the motivation for this behaviour must in part spring from a sense of inferiority felt by eighth-century Greeks in relation to the Age of Heroes. He argues that epic poetry created a new self-consciousness amongst the Greeks of the early Archaic period. Epic presented mainland Greeks with a set of ideals, but also emphasised the gulf that lay between the Age of Heroes and their own, apparently more mundane, existence. (This at least seems to be the feeling that informs the poems of Hesiod.) Epic thus had two effects on eighthcentury Greeks: it spurred them to emulate the ideals and imitate the behaviour of epic heroes; and it forced them to think of means whereby the heroic past could be made a part of the eighthor seventh-century present. To place offerings in Mycenaean tombs was one of the means whereby this assimilation of the past into the present, this re-appropriation of the Heroic Age, could take place. It was by this means, amongst others, that the Heroic Age was transformed into a usable past.

Secondly, Coldstream has noted that this practice was geographically restricted: common in Attica, the Argolid and Messenia, and fairly widespread in Central Greece and the Peloponnese. But it is a practice unknown in Crete or Thessaly, areas of equal renown in the epic tradition. If the practice was indeed caused by the spread of Epic, then we would expect that it would be equally common in these regions as well. Coldstream attributes its absence in these regions to the essential similarity of their burial customs in Geometric times with those of the Mycenaean World. In Crete and Thessaly collective interment in chamber or tholos tombs was still common in the eighth century BC. But to the inhabitants of Messenia, Attica or the Argolid, communities which had for long practised single burial of some kind, Mycenaean tombs would have stood as imposing and ever present reminders of the lost Heroic Age. Cretans and Thessalians however would have been incapable of perceiving the difference between themselves and the Age of Heroes, since there were no Heroic monuments to remind them of the fact. ${ }^{9}$

But there are difficulties with Coldstream's explanations. Firstly, if this practice was caused by the circulation of Epic, why is it that the cults in Mycenaean tombs appear to be directed towards largely anonymous figures? The Iliad and the Odyssey are full of the names of heroes, but there are no dedicatory inscriptions from the Archaic deposits in Mycenaean tombs. The closest we come to such an inscription is the Archaic potsherd found above Grave Circle A at Mycenae, which simply refers to 'the hero'. ${ }^{10}$ Secondly, what is there in the Epic cycle that would lead the inhabitants of Attica or the Argolid to associate tholos or chamber tombs with heroes known from Epic? The descriptions of a hero's funeral in the Iliad (the funerals of Patroclus or Hector) ${ }^{\mathbf{1 1}}$ or of a hero's tomb (the tomb of Ilos) ${ }^{12}$ much more closely resemble

${ }^{6}$ For the Menelaion, see A. J. B. Wace, M. S. Thompson and J. P. Droop, 'Excavations of Sparta 6. The Menelaion', $B S A \times \mathrm{xv}$ (I909) 108-57. There are only a very few dedicatory inscriptions from shrines presumed to be heroa whose series of votive deposits begins in the eighth century or earlier. One is the Polis cave in Ithaca, for which see S. Benton, 'Excavations at Ithaca III', $B S A \operatorname{xxxv}$ (1935) $45-73$, esp. pp. 54-5; another is a small altar close to the Zeus sanctuary on Mt Hymettus with dedications to Herakles; see M. K. Langdon, $A$ sanctuary of Zeus on Mt Hymettus Hesperia Supplement xvi (Princeton 1976) 97-8. Few of the sites with dedications to named heroes bear any obvious archaeological relationship to the practice of placing offerings in Mycenaean tombs discussed in this article.

7 J. M. Cook 'The Agamemnoneion', $B S A$ xlviii (I953) 30-68; see also Cook [n. 2] above.

8 See Cook [n. 4] and Coldstream [n. 5] 9 and I4.
${ }^{9}$ For burial customs see Coldstream [n. 5] I3-I4. A. M. Snodgrass, The Dark Age of Greece (Edinburgh I97I) I 40-2 2 provides a useful summary of the evidence for burial customs in the various regions of Greece between I 100 and $700 \mathrm{BC}$. The eighth century evidence for the burial customs of Attica, the Argolid and Crete is more readily accessible in Coldstream [n. 2] I 19-23 (Attica), I45-6 (the Argolid) and 276-7 (Crete).

10 See $\mathrm{H}$. Schliemann, $A$ narrative of researches and discoveries at Mycenae and Tiryns (London I 878) I I s; and L. H. Jeffery, The local scripts of Archaic Greece (Oxford I96I) I74 n. 6 and plate 3 I.

${ }^{11}$ For the funeral of Patroclus Iliad xxiii 249-57; of Hector Iliad xxiv 790-803. For burial customs see refs in [n. 9] above.

12 Iliad x 4I5; xi I66, 37I-2; xxiv 349. For burial customs see refs in [n. 9] above. 
contemporary burial practices in Attica or the Argolid than they do those of the Mycenaean World. The discontinuity in the use of tombs between the Mycenaean period and Late Geometric times would also lead one to discount an alternative hypothesis, namely that there was a local tradition of veneration of heroes in these places. One must agree with Snodgrass ${ }^{13}$ when he states that many of these heroes must have been unknown, anonymous figures at the time that their cult was instituted: inventions as much as re-discoveries of the late eighth century. This forces us to look for other explanations, both for the origins of this practice and for its strangely limited distribution within the Greek World.

Bérard, ${ }^{14}$ Snodgrass ${ }^{15}$ and de Polignac ${ }^{16}$ have all proposed alternative explanations. More explicitly than Coldstream, they see the phenomenon, not simply as another symptom of an eighth-century interest in the Heroic World, but as an integral, ideological component in the process of state formation. Bérard and de Polignac concentrate on the slightly different (if related) phenomenon of the heroisation of contemporaries and its significance. Such heroisation of the known and recently dead is inferred from archaeological evidence (the establishment of a 'heroon' at Eretria) ${ }^{\mathbf{1 7}}$ and also suggested by contemporary literary descriptions (the 'heroic' funeral games of Amphidamas of Chalcis). ${ }^{18}$ But, in the Archaic period at least, such a practice is confined to the Island of Euboea.

Snodgrass on the other hand deals explicitly with the same phenomenon as Coldstream. Thinking Coldstream's explanation 'too archaeological' he proposes a 'sociological' alternative. ${ }^{19}$ He notes that, with the important exception of Messenia, offerings in Mycenaean tombs occur in areas which were known in historical times to be inhabited by a free peasantry rather than by a dependent population of serfs. Furthermore, offerings in Mycenaean tombs are most commonly found in those areas of Greece for which there are good grounds for believing that there was a noticeable rise in population at the end of the eighth century, whether we take our index as being the number of known settlements or the number of visible graves. ${ }^{20}$ He sees the rise in the number of known sites in these areas as being the result of a process of re-settlement of the land by peasant agriculturalists, land which had lain fallow since Mycenaean times. In his view, the offerings in Mycenaean tombs must have been put there by free peasants who, in moving into new areas, had to propitiate the previous owners, represented by the impressive Mycenaean funerary architecture. In placing offerings in tombs, tombs whose monumental character led them automatically to be associated with the Age of Heroes, they were forging a link with that world, and at the same time establishing the legitimacy of their title to land which they would then farm.

Such explanations however only deal with (and can only account for) the general, geographic spread of finds within Greece. What is needed is an interpretation that takes some cognisance of the character of the deposits in particular areas, and the distribution of finds within particular regions. As will become apparent, the archaeological evidence is much more diverse, and at the same time more informative, than a casual reading of either Snodgrass' or Coldstream's articles would lead one to suppose.

13 A. M. Snodgrass, 'Les origines du culte des héros dans la Grèce antique', in G. Gnoli and J. P. Vernant (eds.) La mort, les morts dans les sociétés anciennes (Cambridge 1982) 89-105, esp. pp. 107-8. See also Snodgrass [n. 2] ibid.

14 C. Bérard, 'Récupérer la mort du prince: heroïsation et formation de la cité,, in G. Gnoli and J. P. Vernant (eds.) La mort, les morts dans les sociétés anciennes (Cambridge 1982) 89-105.

15 Snodgrass [n. 2] and [n. 13] above.

16 De Polignac [n. 2] above.

$17 \mathrm{C}$. Bérard, L'héroon à la porte de l'Ouest Eretria iii. (Berne 1970); see also Berard [n. I 4] above. The large tenth-century BC building found at Lefkandi has been described by its excavators as a heroon, and the burial beneath as that of a hero; see M. Popham, L. H. Sackett and E. Touloupa, 'The hero of Lefkandi', Antiquity lvi (1982) 169-74. This characterisation seems to me to be extremely unlikely, and indeed has not won general acceptance; see de Polignac [n. 2] 92 n. I46.

${ }_{18}$ Hesiod Works and Days 654-9.

19 Snodgrass [n. I3] I I $4-16$. The characterisation of Coldstream's explanation as 'too archaeological' is remembered from a conversation.

${ }^{20}$ For the expansion of population, with indices, see Snodgrass [n. 2] 20-4 and A. M. Snodgrass, Archaeology and the rise of the Greek state (Cambridge 1977). More up-to-date figures, with useful comparisons with other regions, can be found in I. M. Morris Burial and ancient society (Cambridge 1987) I 56-9, fig. 54 and tables 12 and 13 . For the 'peasant agriculturalist' hypothesis see Snodgrass [n. I3] 1 I6-18 and [n. 2] 36-40. 


\section{The Situation in Attica}

Late Geometric or Archaic offerings have been found in the following Mycenaean tombs in Attica:

MENIDHI: Tholos tomb. The finds from this tomb comprise both Late Geometric and Protoattic kraters and pedestalled kraters, some early black figure vases (including a vase by Sophilos), and 22 votive clay shields, probably of seventh-century date. ${ }^{21}$

THORIKOS: Early Mycenaean oval tholos tomb (tomb I, of 'intermediate type'). The seventh-century finds from this tomb comprise large numbers of Protoattic vases and Protocorinthian ovoid aryballoi, the sixth-century finds being Corinthian aryballoi and skyphoi, and Attic black figure lekythoi. ${ }^{22}$

ALIKI GLYPHADHA: Mycenaean chamber tomb, tomb dhelta. The finds from this tomb consist solely of a Late Geometric pyxis with lid. ${ }^{23}$

In addition to these, it has frequently been claimed that the finds from the Erechtheum on the Acropolis, ${ }^{24}$ the Academy, ${ }^{25}$ and Eleusis also indicate that a hero cult was established in each of these places in the late eighth century. But the evidence from both the Academy and the Erechtheum is confused, such that one cannot distinguish the concrete evidence from the excavator's interpretative claims. An Early Geometric child's grave in the Agora became the locus for some kind of cult in the seventh century, but this does not come into the category of Geometric offerings in Mycenaean tombs considered here, and its significance is as yet unclear. ${ }^{26}$ Only the evidence from Eleusis stands up to any scrutiny. ${ }^{27}$ Here seven LH III cist tombs of Middle Helladic type were enclosed in the eighth century by a wall, and Late Geometric potsherds were found in the general area. It is thought that it is this enclosure that was pointed out to Pausanias as being the tomb of the Seven against Thebes. ${ }^{28}$ Insofar as it represents the establishment of a cult in Late Geometric times over earlier Bronze Age tombs, where the identity of the hero must have been a matter of guesswork, it is clearly linked to the offerings at Menidhi, Thorikos and Aliki.

${ }^{21}$ For the tomb at Menidhi see H. G. Lolling, Das Kuppelgrab bei Menidi (Athens I 880). For the eighth and seventh century BC finds see P. Wolters 'Vasen aus Menidi II', Jdl xiv (I 899) I03-35; Geometric krate pp. I IO-II and figs I8, I9 and 27; Protoattic kraters pp. I Io-I I and figs I6, I 7 and 28; clay votive shields p. I 8 and fig. 25. R. Hägg, 'Gifts to the heroes in Geometric and Archaic Greece', in T. Linders and G. Nordquist (eds.) Gifts to the Gods (Boreas xv, Uppsala 1987) 93-9 esp. 94-6 discusses the character of the finds from Menidhi. For the vase by Sophilos, and an inconclusive discussion of how the inscriptions are to be read see $\mathrm{P}$. Wolters, 'Vasen aus Menidi I', JdI xiii (I 898) I 3-28.

22 For Thorikos see J. Bingen et al., Thorikos i. 1963 (Brussels I965) 9-Is.

${ }^{23}$ For Aliki Glyphada see I. Papadimitriou, $P A E$ 1955 78-99 esp. pp. 96-7 and plate $28 \mathrm{e}$.

24 See S. Iakovides, I Mikinaiki Akropolis (Athens I962) I 86 n. 36I for the 'Submycenaean' vases apparently indicating Dark Age cult. For early mention of Erechtheus and his House Iliad ii 546-56; Odyssey vii 8 I. Generally, see Coldstream [n. 5] i 6 for a discussion of the question.

${ }^{25}$ For the Academy, see P. D. Stavropoullos, PAE $19585^{-1} 3$ and H. Drerup, Griechische Baukunst in geometrischer Zeit (Archaeologia Homerica vol. O, Göttingen I969) 3 I-2. See Snodgrass [n. 9] 398 and 439 n. 37 for further references.
26 An oval structure with a later Protoattic votive deposit was constructed over a Protogeometric child's grave in the Agora; see D. Burr, 'A Geometric house and a Protoattic votive deposit' Hesperia ii (1933) $54^{2-}$ 640. Burr thought this structure was simply a house, but H. Thompson, Hesperia xxxvii (1968) 58-60 has reinterpreted it as an early shrine, dedicated to the cult of the dead, which most scholars now think more likely. Although the character of the finds from this Protoattic deposit is remarkably similar to that of those from Menidhi, this does not necessarily provide any grounds for its interpretation as a hero cult, since there is no real homogeneity in either the type or quantity of finds dedicated to heroes; see Hägg [n. 2 I] above $94^{-7}$ and 99. There is only one published Mycenaean grave from Athens where Dark Age remains have been found, but these appear to be associated with a later intrusive burial and not with cult; see E. D. Townsend, Hesperia xxiv (I955) I87-219, esp. 200-I.

27 See G. E. Mylonas, PAE 1955 77-87, esp. pp. 8I6; and G. E. Mylonas, To dhitikon nekrotaphion tis Elefsinos (Athens 1975) vol ii. 153-4 and vol. iii plates lambda and $145 \mathrm{~b}$.

28 G. E. Mylonas, Eleusis and the Eleusinian Mysteries (Princeton 196I) 62-3; Pausanias i 39.2; Plutarch Theseus 29.4-5. 
It would seem then that Geometric and Early Archaic offerings in Mycenaean tombs in Attica are to be found widely distributed within the region, and tend to be found in the countryside rather than in the city of Athens itself. Apart from its predominantly rural distribution, what further characterises the Attic evidence is the isolation of the findspots. With the exception of Eleusis, it is usually only one tomb at any particular site that was selected to receive offerings. This is an Attic pattern, and does not represent a 'Greek norm'.

So far, the distribution and character of finds in or over Bronze Age tombs meets with the requirements of Snodgrass' model. Additional support for his interpretation might be provided by the evidence for settlement expansion in Geometric times. The number of occupied sites rises from the three known to have been occupied at the end of LHIIIC and in Submycenaean, to five or six known from the ninth century to over twenty-eight datable to Late Geometric II. ${ }^{29}$ Many authors have seen this rise, not simply as the result of the re-settlement of fallow land, but as part of a process of internal re-colonisation of the Attic countryside from Athens itself. ${ }^{30}$ In Attica the re-settlement of land and the appearance of offerings in or over Bronze Age tombs are clearly related to one another. If however we are to attribute the institution of this practice to the actions of free peasants wishing to establish their title to land that they would then farm, we would expect such a practice to be most common in the younger and smaller communities of the late eighth century. This we do not find. Instead, in at least three cases (Menidhi, Eleusis and Thorikos) ${ }^{31}$ offerings in tombs and veneration of heroes are to be found at those sites which appear already to have been settled in Protogeometric times. At Menidhi moreover the quality and quantity of finds is more in keeping with the actions of aristocrats than with those of free peasants. Only at Aliki Glyphada is the scale, date and nature of the offering consistent with the action of a free peasant wishing to make his claim to land unoccupied since Mycenaean times. In the majority of cases the practice of placing offerings in Mycenaean tombs appears to be the action, not of the newly founded, but of the older communities within Attica.

29 These figures are based on the number of known sites in Attica with graves with datable grave goods. This information cannot easily be summarised, although all the relevant evidence is listed in Morris [n. 20] Appendix 2 222-33. More detailed lists of the Attic grave evidence can be found in the following unpublished Ph.D. dissertations: W. G. Cavanagh, Attic burial customs 2000-700 BC (London 1977); I. M. Morris, Burial and society at Athens 1100-500 BC (Cambridge I985); A. J. M. Whitley, Style, burial and society in Dark Age Greece (Cambridge I986).

30 Coldstream [n. 2] I 33-5; Snodgrass [n. 2] 23 and $35-6$. This re-settlement hypothesis is based on archaeological evidence, not literary. The literary traditions concerning Theseus' unification of Attica or early wars against an independent Eleusis are so confused that it is impossible by standard philological methods to tease out what truth they might have held. So, although recent discussions of this question by S. Diamant, 'Theseus and the unification of Attica' Studies in Attic epigraphy, history and topography presented to Eugene Vanderpool Hesperia Suppl. xix (Princeton 1982) 38-50 and R. M. Simms, 'Eumolpus and the wars of Athens' Greek, Roman and Byzantine Studies xxiv (1983) I97-208 have opted for a Dark Age or Geometric 'synoecism' I incline to the view that, insofar as they have any historicity at all, such stories refer to the Bronze Age.

The archaeological arguments in favour of the 'resettlement' hypothesis between the roth and 8th centuries BC are: (I) the absence of any settlement outside Athens in Attica at the end of the Submycenaean period; (2) the remarkable similarity both in pot style and burial customs between finds from early ioth9th century burials in Attica and those from Athens itself. Stylistic similarity is particularly evident in the designs on ninth-century belly-handled amphoras. Compare the vase illustrated in Mylonas [n. 28] plate 86 from Eleusis with contemporary examples from Athens; see K. Kübler, Kerameikos v (Berlin I954) plate 46 and E. L. Smithson, Hesperia $x \times x v i i$ (I968) 77-I I6, plate 20. For a fuller discussion see Whitley [n. 29] I0I-7 and I66-93.

${ }^{31}$ This too is based on the evidence from datable grave assemblages, rather than from settlements, and is not easy to check. It is however sufficient to demonstrate continuity of occupation from Protogeometric times.

For Eleusis, see Arch. Eph. 1898 76-122; Arch. Eph. 1912 30-9; CVA Athens $i$ plates I-3; Mylonas [n. 28] plate 86; Mylonas [n. 27] To dhitikon nekrotaphion vols i, ii and iii, graves gamma I6, gamma I 5 , theta 23 , gamma I I, gamma Io, gamma-zeta, gamma 43 , theta 22 and lambda 2.

For Menidhi, see W. Kraiker and K. Kübler, Kerameikos: Ergebnisse der Ausgrabungen i (Berlin 1939) I 57 n. I; CVA Heidelberg iii plate I03 [G52 and $\mathrm{G}_{78}$ ]; Arch. Anz. 1904 40; D. Ohly, Griechische Goldbleche des 8. Jahrhunderts v. Chr. (Berlin I953) I 2 and plate 24.

For Thorikos see Bingen et al. [n. 22] 28-9; Hesperia xxx (I96I) 299-304; J. Bingen et al., Thorikos ii 1964 (Brussels 1967) 26-34 and 33 n. I; J. Bingen et al., Thorikos iii 1965 (Brussels 1967) 43 and 45; J. Bingen et al., Thorikos iv 1966/67 (Brussels I969) 7I-IOI. 
Such practices do then appear to be connected with the late eighth-century population expansion and to land claims. But in other respects the evidence does not support Snodgrass' interpretation. It is more plausible to see the institution of these cults as part of a reaction by settled, richer communities to the founding of small settlements around them, the filling in of the Attic countryside, than it is to attribute them to the actions of land hungry, but easily awed, free peasants. In establishing a link with the heroic past these older communities were making an ideological claim to be of greater antiquity and importance than the newer sites. This must have been more than a claim to the title of the land, for these communities were by now more than two hundred years old. Rather it was a claim to be the true indigenous inhabitants of Attica, worthy successors to the Age of Heroes now being recounted in various epic lays. It may thus be seen as a gesture, a gesture which, in magnifying the antiquity of these sites, was directed as much towards Athens as towards the newer foundations. In so doing, these communities chose to emphasise their local ties, their local autochthony, rather than any links with the urban centre of the state. These were perhaps the actions of an established elite in the Attic countryside, an elite whose existence in the early eighth century is attested by the rich middle Geometric II burials at Anavyssos $^{32}$ and Eleusis, ${ }^{33}$ and the rich Late Geometric interment at Menidhi. ${ }^{34}$

In Attica, hero cults (or at least offerings in Mycenaean tombs) appear to have been instituted by communities who were opposed to the growth of an authority over Attica centred upon Athens itself. It is difficult to see how 'hero cults' could have served as part of the ideological underpinnings of the early polis in the Athenian case. This contrasts sharply with the significance of 'hero cults' in the Argolid.

\section{The Situation in the Argolid}

Unlike Attica, where later Geometric finds in Mycenaean tombs are distributed evenly throughout the Attic countryside, and where such finds are usually restricted to one tomb per site, Geometric and Archaic offerings in Mycenaean tombs in the Argolid are concentrated in three major locations: at Argos, Mycenae and Prosymna (close to the Argive Heraeum). Three tombs from the Deiras cemetery at Argos have offerings of late eighth or early seventh century date. ${ }^{35}$ At Mycenae at least four tholos tombs (the tomb of Clytemnestra, the Epano Phournos, the Kato Phournos and the Lion tombs) have sufficient Geometric and Archaic material from the dromos or chamber to warrant an interpretation of 'hero cults'. ${ }^{36}$ Both Grave Circle A and Grave Circle B appear also to have attracted some kind of cult. ${ }^{37}$ Since, at the time of excavation, all the tombs at Mycenae had already been looted, it is possible that all the tombs here with Geometric or Archaic material may originally have been the locations of hero cults. ${ }^{38}$ There is moreover good evidence for Geometric and Archaic offerings in two chamber tombs (522 and 533) from the Kalkani cemetery nearby. ${ }^{39}$

32 Anavyssos graves I and II; see Arch. Delt B Chronika xxi (1966) 97-8.

33 Eleusis: see CVA Athens $i$ plates I-3; Arch. Eph. 189876 I 22, especially pp. IO3-7 for the Isis grave and p. I03 for grave alpha; see also Coldstream [n. 2] 78-80.

34 Menidhi: see Ohly [n. 3I] Griechische Goldbleche 12 and plate 24; Arch. Anz. 190440.

35 Offerings in tombs in the Deiras cemetery: tomb v, W. Vollgraff, 'Fouilles d'Argos' $B C H$ xxviii (1904) 364-99, esp. pp. 366-7; tombs xiv and xvii, J. Deshayes, Argos: Les fouilles de la Deiras (Paris I966) 2 I5-19 and plates li, lii and lvii.

${ }^{36}$ See A. J. B. Wace, 'Excavations at Mycenae ix: The tholos tombs', $B S A \times x \times$ (1923) 283-407: the tomb of Klytemnestra pp. 357-76 (see also Cook [n. 4] i i $4 \mathrm{n}$. 5 and Schliemann [n. Io] plates 20 and 2I); the Kato Phournos tomb Wace pp. 320-5; the Lion tomb Wace pp. 325-30; the Epano Phournos tomb Wace pp. 292-6, but see also A. J. B. Wace, M. S. F. Hood and J. M.
Cook, 'The Epano Phournos tomb' BSA xlviii (1953) 67-83 esp. pp. 80-I.

37 For Grave Circle A, see Schliemann [n. Io] ibid and Jeffery [n. Io] ibid with references. For Grave Circle B see G. E. Mylonas, O taphikos kiklos B ton Mikinon (Athens 1973) I8, where a 'kiklikon hieron' of historical date is mentioned. There appear to have been no Archaic deposits directly over Grave Circle B, but a chamber tomb nearby attracted Late Geometric offerings, including a krater; see I. Papadimitriou, $P A E 1952$ 470 fig. 35 and $P A E 1953208$ n. I.

38 See Wace [n. 36] $B S A \operatorname{xxv}$ (1923) 283-407. In addition to those already mentioned, these would include the Cyclopean tomb p. 292; the Panagia tomb pp. 3 16-20; and the tomb of the Genii pp. 376-87.

${ }_{39}$ A. J. B. Wace, 'Chamber tombs at Mycenae', Archaeologia lxxxii (Oxford I932); tomb 522 pp. 3 I-4; tomb 533 pp. I I3-20. 
The third major concentration of Mycenaean tombs in the Argolid with Geometric or Archaic finds is to be found in the Prosymna cemetery, close to the major state sanctuary of Argos, the Heraeum. ${ }^{40}$ The character of the Archaic finds from these tombs, in particular the wealth of bronze items (long pins, fibulae, mesomphalic phialai, bronze discs and cutouts) is remarkably similar to that of Late Geometric and Archaic finds both from the Argive Heraeum itself ${ }^{41}$ and from a small Archaic shrine excavated by Blegen nearby. ${ }^{42}$ It is not then too fanciful to suppose that, in the vicinity of the Argive Heraeum at least, the difference between a 'hero cult' and other kinds of cult was not so very great, and that the appearance of offerings in these tombs must be intimately related to the construction and foundation of the Argive Heraeum itself. Indeed one could go further, and suggest that the motivation for the construction of the Heraeum, a site which served as the major state sanctuary for the Argive state, and for the placing of offerings in tombs nearby must have been largely the same. This leads on directly to a consideration of the politics of cult in the Argolid in the late eighth-century BC. But, before doing so, it is worthwhile underlining some important differences between the general political situation in Attica and in the Argolid in the Archaic period.

One difference is so obvious that it may hardly seem worth mentioning. Though the Argolid and Attica were areas of equivalent size, Attica was united politically, but the Argolid was, more often than not, divided into a number of sovereign poleis: Argos, Tiryns, Mycenae and (for a short time) Asine. Whereas the unity of Attica seems to have been maintained almost effortlessly (there were no serious separatist movements in Attica), the history of the Argolid during the Archaic and early Classical periods is marked by frequent military attempts by Argos to maintain its hegemony over the region. ${ }^{43}$ Argos clearly had a need for military equipment and organisation that was never keenly felt by Athens, a need which became apparent early on. A peculiarly Argive interest in the development of military equipment is attested as early as the

40 Blegen [n. 3] and C. W. Blegen, Prosymna: the late helladic settlement preceding the Argive Heraeum (Cambridge 1937). Eleven tombs received later Geometric and Archaic offerings:

T. xix Prosymna 6r;

T. xxv Prosymna 86-92 and Blegen [n. 3] 386;

T. xxvi Blegen [n. 3] 378;

T. xxxiv Prosymna I IO-I6 and Blegen [n. 3] figs Io and I 2;

T. xxviii Blegen [n. 3] 379 and fig. 2;

T. $\mathrm{xl}$ Prosymna $\mathrm{I} 33-5$;

T. xlix Prosymna I 35-40 and Blegen [n. 3] 379;

T. 1 Prosymna I 40-2 and Blegen [n. 3] 389 and fig. I4;

T. viii Prosymna I60-4 and Blegen [n. 3] 378 and figs $4,5,6$ and 8 ;

T. ix Prosymna $164-6$ and Blegen [n. 3] 378;

T. $x$ Prosymna 197-200 and Blegen [n. 3] 380 .

Tombs iii and xiii are also mentioned as having received Archaic offerings, but the evidence does not bear any scrutiny. Only tombs xix, xxvi, xxxiv, 1 , viii and $x$ received bronze finds similar to those from the Argive Heraeum.

41 See C. W.aldstein, The Argive Heraeum ii (Boston I905) I9I-33 I for the bronzes and IOI-59 for the Geometric and Archaic pottery. See Hägg [n. 2I] 93 for a further discussion of the character of the finds from both the tombs and the Heraeum.

42 C. W. Blegen, 'Prosymna: Remains of post- mycenaean date', $A J A$ xliii (1939) 4IO-44. For the shrine see pp. 410-27. Other possible votive Archaic material was found at 'the bridge' pp. 427-30; on the Acropolis pp. 430-7; and on the SW slope below the small sanctuary pp. $437-44$.

43 The independence of Mycenae and Tiryns in the later Archaic period is shown by their willingness and their ability to contribute to the defence of Greece against the Persians while Argos stood aloof; Tiryns sent contingents to Plataea, and Mycenae sent a detachment to both Plataea and Thermopylae (Hdt vii 202; ix 29.4; ix 3 I.3). For this act of defiance both cities were destroyed by the Argives soon afterwards (Pausanias v 23.2-3; ii I6.5; ii 25.8). For the earlier Archaic period we lack literary testimony. But the construction of stone temples between $740-550 \mathrm{BC}$ over the sites of former Mycenaean palaces at Mycenae and Tiryns argues for at least a degree of independence at this time; for Tiryns see A. Frickenhaus, 'Die Hera von Tiryns' Tiryns i (Athens I9I2) 2-I07; for Mycenae see A. J. B. Wace, Mycenae: an archaeological history and guide (Princeton I949) 84-6. Moreover, according to Jeffery [n. Io] I 4950 , the letter forms at Tiryns are decidedly un-Argive. Even if this does not prove the independence of these communities, those scholars who wish to see both Tiryns and Mycenae as perioecic communities, dependencies of Argos, before Kleomenes' invasion of 494 BC (Hdt. vi $74^{-84}$ ) would still have to agree that the political structure of Argos and that of Attica were very different in the Archaic period. 
eighth century, ${ }^{44}$ and Argos is thought to have been responsible for the destruction of Asine at this early date. ${ }^{45}$

If the determination of Argos to impose its rule over the region is well documented, it remains unclear why Argos experienced such difficulties in creating a 'United Argolid' where Athens in a similar situation appears to have encountered none. But if we accept the hypothesis that the Attic countryside was re-colonised from the city of Athens itself during the Dark Ages, this perhaps becomes easier to explain: all the inhabitants of Attica would have ultimately been (or believed themselves to have been) Athenian; the notion of Attic unity would have been maintained by a kind of fictive kinship solidarity. ${ }^{46}$ But this 're-colonisation' hypothesis cannot be made to fit with the archaeological evidence from the Argolid during the same period. In the Argolid, the increase in the number of graves (which parallels the situation in Attica, and, as in Attica, has been used to support the notion that there was a significant increase in population in the late eighth century) ${ }^{47}$ is not accompanied by an increase in the number of sites to nearly the same extent. ${ }^{48}$ It is difficult to think of the Argolid as having been re-colonised in the Early Iron Age solely from Argos itself. Rather, each of the Late Bronze age communities (Argos, Asine, Tiryns, Mycenae and perhaps Nauplion) appears to have been occupied throughout the Dark Ages, and then to have emerged (if only briefly in the case of Asine) as independent poleis at the end of the eighth century вС. ${ }^{49}$ Unlike Athens, Argos faced the problem of trying to enforce its authority throughout a region filled with competing, independent sovereign city states. Its 'solution' was finally military: it simply razed all other centres to the ground. ${ }^{50}$ This 'military solution' however cannot have been entirely satisfactory: the neighbouring territories were depopulated and so weakened, but there was no concomitant increase in the manpower or resources of the Argive state. Paradoxically, the most successful territorial aggrandizement of the Argive state seems to have been achieved at the time of its emergence as a polis, and seems to have been achieved by non-military means. It is time to examine the politics of cult in the Argolid in the eighth and seventh centuries BC.

De Polignac has argued cogently for the crucial role played by the establishment of extraurban sanctuaries in the formation and territorial definition of the early city-state. ${ }^{51}$ Foundations such as the temples at Perachora, the temple of Aphaia on Aegina and the Argive Heraeum itself were placed on the boundaries, on the eschatia of a city's territory. The establishment of regular cult practices on these sites served two purposes: it laid claim to the territory within the vicinity of the sanctuary, and so established the state's title to the land; and it helped to integrate the more distant, the less settled regions of the polis with its urban, or proto-urban centre. Like the

44 See P. Courbin, 'Une tombe géométrique d'Argos', $B C H$ lxxxi (I957) 322-86 and A. M. Snodgrass, Early Greek armour and weapons (Edinburgh 1964) 200.

45 Coldsteam [n. 2] i 52-4. This event is recorded by Pausanias (ii $36.4-5$; iii 7.4 ; iv 8.3 ; iv I4.3). See also O. Frödin and A. W. Persson, Asine: Results of the Swedish excavations 1922-1930 (Stockholm 1938) 3 I 2-33 and 437.

46 It might be thought that recent French scholarship had overturned the notion that Archaic Athens was organised along either 'tribal' lines or along lines of kingroupings. Insofar as the belief that later, Classical institutions such as the phratry, genos and phylai were 'Archaic survivals' which had persisted into the Classical period has been shattered by the work of F. Bourriot, Recherches sur la nature du gènos (Lille 1976) and D. Roussel, Tribu et cité (Paris 1976), this statement is correct. However what these scholars have indirectly underlined is the importance of the language of kinship in maintaining the sense of unity, the corporate identity of a state the size of Classical Athens, although the groups so designated were not in fact kinship groups at all. Nonetheless it appears that Classical Athens, which stood as the paradigm for rational democratic republican politics for modern generations, was sustained in part by an ideology (and a fiction) of a solidarity of blood.

47 See Snodgrass [n. 2] 22-4.

48 This generalisation is derived largely from the evidence provided by R. Hägg, Die Gräber der Argolis $i$ (Boreas 7.I, Uppsala I974) I 3-I 7. Recent work by the Germans at Tiryns and the Swedes at Asine, for example B. Wells, Asine ii. Fasc 4 (Stockholm 1983) has supported rather than undermined the impression of greater continuity in settlement in the Argolid compared with Attica. Lerna and the Heraeum were the only new sites in the eighth-century Argolid; Dendra and Berbati may be earlier.

${ }^{49}$ See n. 43 and n. 45 above and Hägg [n. 48]

50 See n. 43 and n. 45 above.

51 De Polignac [n. 2] 4I-92. 
establishment of hero cults, the institution of extra urban sanctuaries was an essential component in the processes of state formation.

For de Polignac, Argos is the norm, and Athens (une cite monocentrique) the exception: Argos serves as the paradigm for his 'cité bipolaire' and his 'cité cultuelle'. ${ }^{52}$ It can hardly then be coincidence that two of the densest concentrations of offerings in Mycenaean tombs occur at the two extremities of this 'twin-poled' city, the town of Argos and the Argive Heraeum. For this reason it is difficult to believe that the offerings in the Deiras cemetery, close to the urban centre of the city, or near the Argive Heraeum, its secondary, ritual focus, were the result of actions by free peasants wishing to establish their title to land that they would then farm. For one thing, it is far from certain that the Argolid was inhabited by a free peasantry in Archaic times, rather than by a dependent population of serfs. ${ }^{53}$ For another, if 'free peasants' had chosen to establish their title to land in this way, we would expect a more dispersed pattern of finds than appears to be the case in the Argolid, and we would also expect that offerings would be most common in the newly founded sites. Instead we find two concentrations of offerings in tombs at the two major foci of one city state, and another concentration around the urban centre of a second city state. In the Argolid 'hero cults' appear to have been as politically motivated as other kinds of cult. Like the establishment of the Heraeum itself, the placing of offerings in the chamber tombs at Prosymna was a political act, if not directed by at least encouraged by the state. It was an act that legitimised the rights of Argives as a group to the territory previously occupied by the older, 'heroic' inhabitants of the land. It was as Argive citizens, rather than as free peasants, that eighthcentury Argives instituted the practice of placing offerings in Mycenaean tombs.

This political interpretation of 'hero cults' helps us to explain the situation at Mycenae. The foundation of a major Argive sanctuary within an hour's walking distance from their city, and the implicit claim to the title of the land that this and the offerings in the chamber tombs at Prosymna represented cannot but have been perceived by the people of Mycenae as a provocation. It was a threat, not merely to their political independence, but to any privileged claim to be the heirs of Agamemnon at a time when the Heroic Age had begun to assume an unprecedented ideological importance. In this light the large number of both tholos and chamber tombs that received later offerings at Mycenae, and the need to reclaim the persona of Agamemnon for their city which manifested itself in the institution of a cult to his name, ${ }^{54}$ are hardly surprising developments.

\section{Conclusions}

The significance of the emergence of 'hero cults' (in the special sense used in this article) in both Attica and the Argolid seems then to be much more directly political than some other authors have allowed for. In neither case can an interpretation which sees the offerings in Mycenaean tombs as the actions of colonising peasant agriculturalists be sustained. There are equal difficulties with the view that such practices were caused solely by the circulation of Epic. In Attica such cults were instituted by communities which had been established by the ninth century, communities which appear to have been acting on their own and not on the state's behalf. In the Argolid by contrast the foundation of such cults seems to relate much more directly to the ideological needs of the early city states. Offerings in Mycenaean tombs, like the foundation of urban and extra-urban sanctuaries, were part of the means by which the city defined its territorial limits and established a beneficial relationship to a usable, ideological past.

52 De Polignac [n. 2] 4I-92 and I 53-7.

53 It would be difficult to explain the role of the douloi mentioned in Hdt. vi 83 unless we see them as agricultural serfs. I owe this reference to Anthony
Snodgrass who now feels 'much less convinced' by his hypothesis of hero cults being instituted by a free peasantry.

54 See Cook [n. 4] and [n. 7] above. 


\section{AdDENDUM}

Since I originally submitted this article, Nicolas Coldstream has read it and made some valuable comments. He points out that many of my arguments for the 'political' significance of the offerings in Mycenaean tombs at Prosymna had been anticipated by James C. Wright, 'The Old Temple terrace at the Argive Heraeum and the early cult of Hera in the Argolid', JHS cii (1982) I 82-20I, esp. p. I93. Figures for the relative numbers of eighth-century sites and sites of earlier date in the Argolid may also have to be revised in the light of Anne Foley's An Archaeological survey of the Argolid 800-600 BC (Studies in Mediterranean Archaeology), which I have not yet seen.

There remains the unresolved problem of the political significance of 'hero cults' in Messenia. I have avoided this question, partly because the popularity of these cults in an area inhabited by dependent helots (serfs) does not fit satisfactorily into anyone's explanatory models. Some light on this subject may be shed by W. E. Coulson, 'Geometric pottery from Volimidia', $A J A$ xcii (1988) 53-74, although he does not go into the question of the significance of hero cults in Messenia in Geometric times.

\section{ACKNOWLEDGEMENTS}

I would like to thank Anthony Snodgrass for helpful comments on an earlier draft of this paper, and the anonymous referee of $J H S$ for pointing out certain deficiencies in the argument. Any mistakes are of course my own.

British School at Athens

JAMES WhitLEY 